\title{
Crop raiding by wild mammals in Ethiopia: impacts on the livelihoods of smallholders in an agriculture-forest mosaic landscape
}

\author{
Tola Gemechu Ango, Lowe Börjeson and Feyera Senbeta
}

\begin{abstract}
We assessed the impacts of crop raiding by wild mammals on the livelihoods of smallholding farmers in south-western Ethiopia. Data were generated through participatory field mapping, interviews and focus groups. The results indicated that wild mammals, mainly olive baboons Papio anubis and bush pigs Potamochoerus larvatus, were raiding most crops cultivated in villages close to forests. In addition to the loss of crops, farmers incurred indirect costs in having to guard and cultivate plots far from their residences, sometimes at the expense of their children's schooling. Raiding also undermined farmers' willingness to invest in modern agricultural technologies. Various coping strategies, including guarding crops and adapting existing local institutions, were insufficient to reduce raiding and its indirect impacts on household economies to tolerable levels, and were undermined by existing policies and government institutions. It is essential to recognize wild mammal pests as a critical ecosystem disservice to farmers, and to identify ways to mitigate their direct and indirect costs, to facilitate local agricultural development and livelihood security, and integrate wildlife conservation and local development more fully in agriculture-forest mosaic landscapes.
\end{abstract}

Keywords Agriculture, development, ecosystem disservice, Ethiopia, forest, human-wildlife conflict, Oromia, pest

\section{Introduction}

T uman-wildlife conflicts at agriculture-forest inter1 faces and around protected areas have been recognized as having negative effects not only on agricultural production but also on rural livelihoods more broadly (Thirgood et al., 2005; Mackenzie \& Ahabyona, 2012). Some wild mammals reduce agricultural production through crop raiding or depredation of livestock (Weladji \& Tchamba, 2003; Mc Guinness \& Taylor, 2014). In addition to the direct cost of crop loss there are substantial indirect

Tola Gemechu Ango (Corresponding author) and Lowe BörJeson Department of Human Geography, Stockholm University, Sweden

E-mail tola.gemechu@humangeo.su.se

Feyera Senbeta Center for Environment and Development Studies, College of Development Studies, Addis Ababa University, Ethiopia

Received 23 June 2015. Revision requested 21 July 2015.

Accepted 24 December 2015. First published online 3 May 2016. costs associated with wild mammal pests, including the additional time and resources required to replant and protect crops (Hill, 2000); absenteeism from school as children provide additional labour for crop protection (Haule et al., 2002); lower educational achievement (Mackenzie \& Ahabyona, 2012); reduced likelihood of boys completing primary education (Mackenzie et al., 2015); and injury and disease arising from contact with pests (Thirgood et al., 2005). However, compared to direct costs, our understanding of the indirect costs of pests is limited (Barua et al., 2013); for example, little is known about the effects pests may have on farmers' willingness to invest in improved agricultural technologies. As well as impeding rural development, the indirect costs of crop raiding coupled with yield loss and state policies prohibiting hunting could reduce farmers' tolerance of crop raiding by wildlife (Naughton-Treves, 1997; Madden, 2008), posing a challenge to wildlife conservation (Dixon et al., 2009; Marchini \& Crawshaw, 2015).

In addition to the strategies employed by farmers to mitigate crop raiding and depredation of livestock by wild mammals (Osborn \& Hill, 2005; Tweheyo et al., 2012), external interventions, such as compensation programmes, have been undertaken in various settings, with mixed results (Nyhus et al., 2005). Compensation schemes have been constrained by lack of financial resources and the high transaction costs involved in verifying farmers' claims (Nyhus et al., 2005; Seifu \& Beyene, 2014). Culling is an alternative externally supported strategy to mitigate human-wildlife conflict but it is considered less viable as a long-term strategy because populations of culled species may recover and subpopulations may be replaced through immigration (Treves \& Naughton-Treves, 2005; Strum, 2010).

Given these challenges there is a need for alternative approaches focused on local-based mitigation strategies (Dixon et al., 2009), while addressing the problem in a broad societal context that is explicit about various stakeholder interests, including conservation and development, and how underlying social conflicts and tensions shape humanwildlife conflicts (Dickman, 2010; Laudati, 2010; Hill, 2015; Redpath et al., 2015). Critical analysis of how a range of indirect effects, including various costs related to mitigation of damage, affect local livelihood opportunities, attitudes, and development and conservation efforts remains an important basis for such a broader societal analysis.

In western and south-western Ethiopia conflicts between people and wild mammals, including olive baboons Papio 
anubis, vervet monkeys Cercopithecus aethiops and bush pigs Potamochoerus larvatus, are a common problem at forest margins (Quirin \& Dixon, 2012; Lemessa et al., 2013; Samnegård et al., 2014). In the Gera-Gomma landscape in south-western Ethiopia, which was the focus of this investigation, farmers had not made any changes to crop mix or land use to counteract the pest problem despite frequent crop raids being reported in villages near forest edges (Lemessa et al., 2013). This suggests that farmers may use other strategies to deal with crop pests. Although various pest mitigation strategies have been reported, including guarding of crops (Lemessa et al., 2013), removal of trees from cropland, and migration (Ango et al., 2014), there is a lack of knowledge about the relative importance of such strategies and how well farmers living close to forests in the Gera-Gomma landscape are able to deal with crop pests.

One of the little understood aspects of how smallholder farmers in Ethiopia deal with pest problems is how local institutions are mobilized to reduce the damage caused by pests (but see Dixon, 2008; Dixon et al., 2009). To address the need for improved understanding of the effects of pests, including indirect costs and impacts on development potential in the agriculture-forest mosaic landscapes of south-western Ethiopia, we investigated the strategies used by farmers in the Gera district to deal with crop raiding by forest-dwelling wild mammals, the effectiveness of these strategies, and the broader impact of this specific ecosystem disservice (Zhang et al., 2007) on local livelihoods and rural development.

\section{Study area}

The study was undertaken in the Gera district of the Oromia region of Ethiopia (Fig. 1). Gera is inhabited by c. 135,000 people, $95 \%$ of whom are smallholding farmers (CSA, 2013) engaged in crop and livestock production. Most farmers produce cereals, such as maize Zea mays, tef Eragrostis tef, wheat Triticum spp., barley Hordeum vulgare and sorghum Sorghum bicolor. Other common crops include pulses, namely field beans Vicia faba and peas Pisum sativum, vegetables, fruits and tubers, including enset Ensete ventricosum, taro Colocasia esculenta and yam Dioscorea spp. Coffee Coffea arabica is the main cash crop, and many farmers produce honey. The total area of the district is $1,454 \mathrm{~km}^{2}$, c. $60 \%$ of which is covered by forests and semi-managed coffee forest (T.G. Ango et al., unpubl. data), which are owned and managed by the state-owned Oromia Forest and Wildlife Enterprise Jimma Branch Office. In addition to using the semi-managed coffee forest, farmers customarily collect coffee and other non-timber forest products from forests.

\section{Methods}

Data were collected from farmers living in villages located along eight transects in Dusta, Gara Naso, Muje, Sadi
Loya and Wanja Kersa kebeles (Fig. 1), during four periods of fieldwork between 2011 and 2013 (Table 1). A kebele is a lower administrative unit that comprises several villages. Six $1-\mathrm{km}$ and two $3-\mathrm{km}$ transects, four along forest edges and four $2-3 \mathrm{~km}$ from forests, were marked on Google Earth (Google Inc., Mountain View, USA) and located using a global positioning system. The transects were located strategically to capture differences in approaches to pest management between farmers living close to and at a distance from forests. Many wild mammal pests remain within $2 \mathrm{~km}$ of forest edges (Lemessa et al., 2013). The 1st fieldwork period covered farmers living along four of the six $1-\mathrm{km}$ transects, and the 2nd and 3 rd periods covered farmers living along all six transects (see Table 1 for details of the research strategy, duration of each fieldwork period, and data generated). The $4^{\text {th }}$ fieldwork period covered farmers living along the two $3-\mathrm{km}$ transects, which were used to incorporate a greater diversity of participants. Together the fieldwork periods covered all crop production stages and cropping seasons.

We used a mixed research design (Bryman, 2012) and collected data using various methods: participatory field mapping, semi-structured interviews, a semi-structured questionnaire survey and focus group discussions. During the 1st and 2nd fieldwork periods we collected land management data for 213 and 349 fields used by 21 and 54 farmers, respectively (Table 2). Most fields were mapped by recording their geographical coordinates and/or by identifying and outlining them on satellite image printouts, which were used for reference in interviews with farmers. The fields included home gardens, annual crops, coffee land and grazing land. For this study, however, we only used data on crop raiding by wild mammals on annual crop fields, home gardens and coffee land (i.e. a total of 147 and 253 fields from the 1st and 2nd fieldwork periods, respectively; Table 2).

The farmers interviewed in the 1st fieldwork period were selected purposively from various age (older, $>50$; middle aged, 36-50; younger, $\leq 35$ years) and gender (female- and male-headed households) categories to obtain a diversity of qualitative data on experiences and perceptions from a relatively small number of informants. All female-headed households, which were fewer in number, were interviewed during the 1 st and 4 th fieldwork periods. During the 2nd fieldwork period farmers were interviewed using a semistructured questionnaire, and informants were selected through a stratified random sampling technique, using wealth status (as identified by local key informants) as the basis for stratification. The data from various wealth categories were pooled to facilitate statistical tests on the total number of farmers interviewed using the questionnaire. The yield loss for maize, one of the major staple crops in the area, caused by mammal pests in the 2012 cropping season was estimated by a second round of interviews during the 3 rd fieldwork period with 23 of the 54 farmers interviewed in 

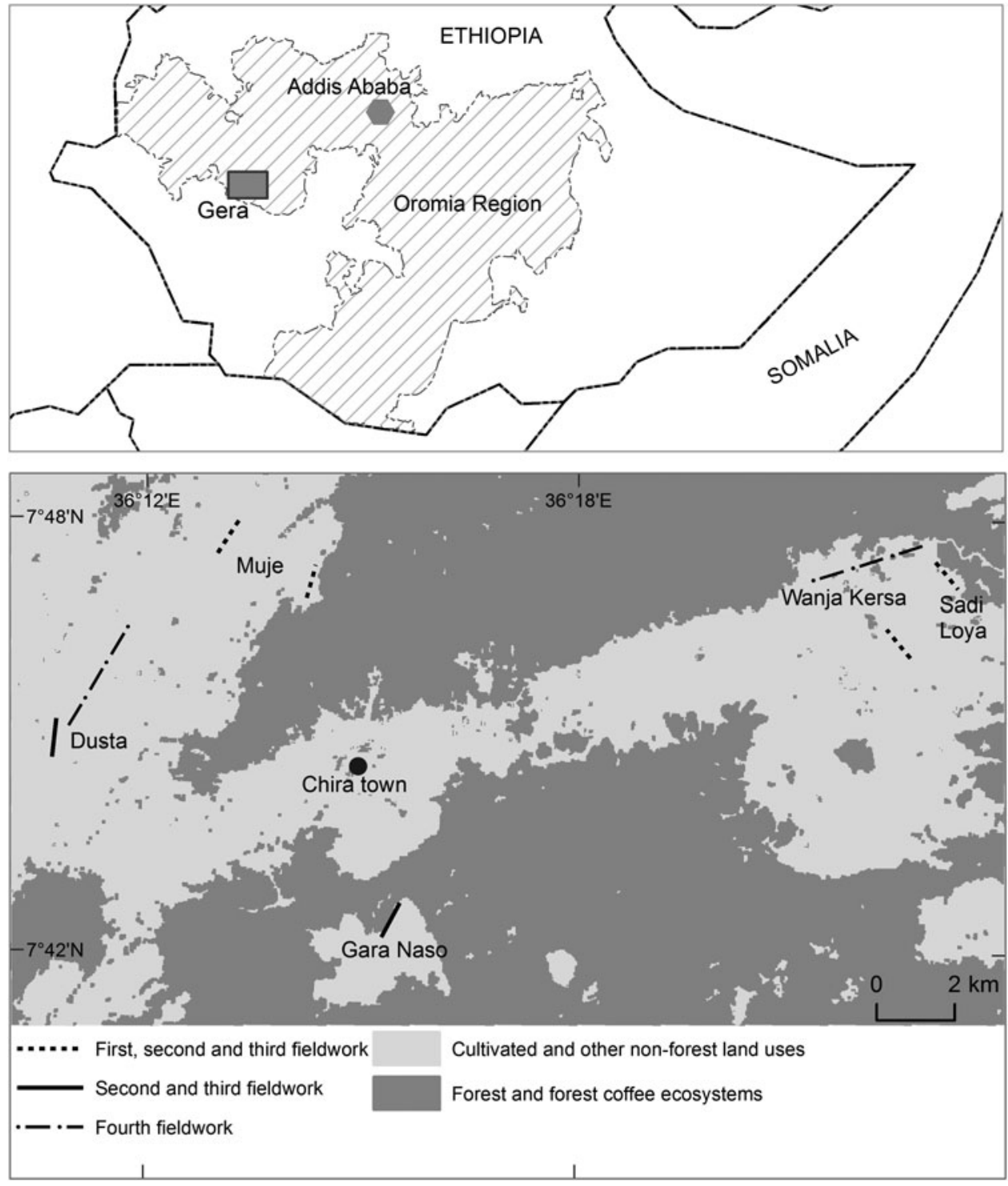

FIG. 1 Location of survey transects in kebeles in the Gera district of Ethiopia. the 2 nd fieldwork period (Table 4). In the 4 th fieldwork period 30 additional farmers (14 from villages near forests and 16 from villages away from forests) were interviewed, to triangulate previous interview data and capture additional data (Table 1). These farmers were selected in the same way as those for the ist fieldwork period.

To rank wild mammal crop raiders based on the level of crop damage they caused, and to identify the major protection strategies employed by farmers, focus group discussions were conducted separately with all-male and all-female groups of 5-9 participants in six villages, three near and three away from forests (Table 1). The all-female focus groups included women who were members of maleheaded households. Directors of six primary schools (four near and two away from forests) and experts at the Gera Agriculture and Rural Development Office were interviewed about wild mammal crop raiders, mitigation strategies and livelihood effects. All interviews were conducted in
Ethiopian languages (two in Amharic, the remainder in Afaan Oromo) without an interpreter. All the farmers selected for interview were willing to participate and share information on all aspects of crop raiding that we asked about. As some of the information shared by informants could be considered sensitive the data were anonymized to avoid exposing participants to risk as a result of sharing their knowledge with us. We reported our findings to farmers and local government offices at various stages of the research via pamphlets in the regional language, Afaan Oromo (Årlin et al., 2015). The distribution of these pamphlets and ensuing discussions facilitated triangulation of information and provided an opportunity to capture updates about trends and patterns in crop raiding after the initial fieldwork.

Qualitative data collected during the various fieldwork periods were combined, sorted and coded to identify the main categories of patterns emerging (Bryman, 2012). All 
TABLE 1 A summary of fieldwork periods, purpose of study, sampling strategy, and data collection methods used in an investigation of crop raiding by forest-dwelling wild mammals and the mitigation strategies used by farmers in the Gera district of Ethiopia (Fig. 1).

\begin{tabular}{|c|c|c|c|}
\hline $\begin{array}{l}\text { Fieldwork } \\
\text { period }\end{array}$ & Purpose of study & Sampling strategy & Data collection methods \\
\hline $\begin{array}{l}3 \text { May-10 July } \\
2011 \text { (1st) }\end{array}$ & $\begin{array}{l}\text { To capture data on experiences \& perceptions } \\
\text { among various categories of farmers; issues } \\
\text { covered included crop raiding species, crop } \\
\text { raiding events, level of damage, protection } \\
\text { strategies \& the impact of pests on livelihoods }\end{array}$ & $\begin{array}{l}\text { Purposively selected farmers (male \& fe- } \\
\text { male) from various age categories }\end{array}$ & $\begin{array}{l}\text { Participatory field map- } \\
\text { ping; interviews; focus } \\
\text { group discussion }\end{array}$ \\
\hline $\begin{array}{l}19 \text { Feb. }-23 \\
\text { Mar. } 2012 \\
\text { (2nd) }\end{array}$ & $\begin{array}{l}\text { To generate data from a randomly selected } \\
\text { larger sample of informants to facilitate } \\
\text { quantitative analysis; issues covered were the } \\
\text { same as in the 1st fieldwork period }\end{array}$ & $\begin{array}{l}\text { Stratified random sampling, using wealth } \\
\text { status (as identified by local key infor- } \\
\text { mants) as the basis for stratification }\end{array}$ & $\begin{array}{l}\text { Participatory field map- } \\
\text { ping; interviews }\end{array}$ \\
\hline $\begin{array}{l}2-14 \text { Oct. } 2012 \\
(3 \mathrm{rd})\end{array}$ & $\begin{array}{l}\text { To obtain estimates of yield loss of maize as a } \\
\text { result of crop raiding in the } 2012 \text { cropping } \\
\text { season }\end{array}$ & $\begin{array}{l}\text { A sample of the farmers participating in } \\
\text { the } 2 \text { nd fieldwork phase }{ }^{*}\end{array}$ & Interviews \\
\hline $\begin{array}{l}4 \text { Oct. }-4 \text { Nov. } \\
2013 \text { (4th) }\end{array}$ & $\begin{array}{l}\text { To triangulate data from previous fieldwork \& } \\
\text { to capture additional qualitative data; issues } \\
\text { covered included patterns of crop raiding, } \\
\text { crop protection strategies \& the impact of } \\
\text { pests on livelihoods }\end{array}$ & Same as the 1st fieldwork phase & $\begin{array}{l}\text { Interviews; focus group } \\
\text { discussion }\end{array}$ \\
\hline
\end{tabular}

${ }^{*} \mathrm{~A}$ total of 36 farmers were identified for the 3 rd fieldwork period by selecting the first six of nine farmers surveyed along each transect in the 2 nd phase. However, data were collected from only 23 of these farmers because the main maize fields of 13 farmers living in high-altitude locations failed completely soon after planting, as a result of insufficient rainfall.

other responses (Tables 2, 4 \& 5) from villages along the transects near and away from forests were pooled separately for each set of data. For the responses from the semistructured questionnaire survey $\chi^{2}$ tests were performed, using $R$ v. 2.15.2 (R Development Core Team, 2012).

Eighty-nine percent of all farmers interviewed represented male-headed households (Table 2). The mean age of the heads of households was 48 years ( 47 and 62 years for male and female household heads, respectively). The mean number of persons per household was six (6.4 and 2.9 for male-headed and female-headed households, respectively). The demographic characteristics and the numbers of annual crops and coffee fields of the interviewed farmers living near and at distance from forests were similar. Crop and livestock production were important livelihood activities for all households interviewed (Table 2).

\section{Results}

Type, spatial patterns and trends of crop raiding by wild mammals

According to the farmers interviewed, common crop raiders included olive baboons, bush pigs, giant forest hogs Hylochoerus meinertzhageni, vervet monkeys, porcupines Hystrix cristata, warthogs Phacochoerus africanus, colobus monkeys Colobus guereza and blue monkeys Cercopithecus mitis (Table 3). A large proportion (79\%) of the annual crop, home garden, and coffee fields were raided by at least one of these mammals during the cropping season (Table 4).
Baboons, bush pigs and vervet monkeys caused damage by eating and trampling a variety of crops, including maize, sorghum, finger millet Eleusine coracana, tubers, vegetables, field beans and peas. Warthogs fed on cereals, mainly tef; olive baboons took maize cobs from granaries and also fed on young sheep and poultry; giant forest hogs damaged crops in home garden and open fields, mainly by trampling; porcupines mainly raided enset, vegetables and tubers; and olive baboons and blue monkeys damaged coffee berries and trees. Olive baboons, vervet monkeys and colobus monkeys also caused damage by eating fruits.

The wild mammal pests and the number of fields they raided varied between villages near and away from forests (Tables 3 \& 4). Farmers ranked baboons and bush pigs as the top crop raiding pests in villages near forests (Table 3 ). In villages located away from forests only a few wild mammals commonly raided crops (Table 3 ) but vervet monkeys were reported as a pest in all such villages. The proportion of fields raided by pests was significantly higher in villages near forests compared to those located away from forests (Table 4; annual crop fields, $\mathrm{P}=0.037$; all fields, $\mathrm{P}=0.020$ ).

Approximately 67 and $48 \%$ of the interviewed farmers in villages near and away from forests, respectively, reported an increasing trend in the severity of crop raids by wild mammal pests in recent years but the difference was statistically insignificant (Table 4). According to farmers there were two major reasons for the increase in crop raids: a reduction of hunting activities, and ongoing land use change primarily related to coffee production. The state began confiscating rifles in the mid 1990s, and hunting of wildlife was prohibited 
TABLE 2 The number of farmers interviewed along transects near and away from forests in the Gera district of Ethiopia (Fig. 1) during the 1st, 2nd and 4th data collection periods (Table 1), their gender, major sources of livelihood, and the number of fields studied.

\begin{tabular}{|c|c|c|c|c|c|c|c|c|c|c|}
\hline \multirow[b]{2}{*}{$\begin{array}{l}\text { Period of data } \\
\text { collection }{ }^{1}\end{array}$} & \multirow[b]{2}{*}{$\begin{array}{l}\text { No. of farmers } \\
\text { interviewed }\end{array}$} & \multicolumn{2}{|c|}{ Gender (\%) } & \multicolumn{3}{|c|}{ Major sources of livelihood (\%) } & \multicolumn{4}{|c|}{ No. of fields studied } \\
\hline & & Male & Female & $\begin{array}{l}\text { Crop \& livestock } \\
\text { production }\end{array}$ & $\begin{array}{l}\text { Crop } \\
\text { cultivation }\end{array}$ & Other $^{2}$ & $\begin{array}{l}\text { Annual } \\
\text { crop }^{3}\end{array}$ & $\begin{array}{l}\text { Home } \\
\text { garden }\end{array}$ & Coffee $^{4}$ & Total \\
\hline \multicolumn{11}{|l|}{ Near forests } \\
\hline 1st & 10 & 80.0 & 20.0 & 80.0 & 10.0 & 10.0 & 48 & 10 & 14 & 72 \\
\hline 2nd & 27 & 96.3 & 3.7 & 81.5 & 3.7 & 14.8 & 71 & 29 & 27 & 127 \\
\hline 4th & 14 & 85.7 & 14.3 & 92.9 & 7.1 & 0.0 & & & & \\
\hline Total & 51 & 90.2 & 9.8 & 84.3 & 5.9 & 9.8 & 119 & 39 & 41 & 199 \\
\hline \multicolumn{11}{|c|}{ Away from forests } \\
\hline $1 \mathrm{st}$ & 11 & 81.8 & 18.2 & 63.6 & 36.4 & 0.0 & 55 & 13 & 7 & 75 \\
\hline 2nd & 27 & 88.9 & 11.1 & 74.1 & 7.4 & 18.5 & 82 & 27 & 17 & 126 \\
\hline 4 th & 16 & 87.5 & 12.5 & 68.8 & 25.0 & 6.2 & & & & \\
\hline Total & 54 & 87.0 & 13.0 & 70.4 & 18.5 & 11.1 & 137 & 40 & 24 & 201 \\
\hline \multicolumn{11}{|c|}{ Total for all transects } \\
\hline 1 st & 21 & 81.0 & 19.0 & 71.4 & 23.8 & 4.8 & 103 & 23 & 21 & 147 \\
\hline 2nd & 54 & 92.6 & 7.4 & 77.8 & 5.6 & 16.6 & 153 & 56 & 44 & 253 \\
\hline 4 th & 30 & 86.7 & 13.3 & 80.0 & 16.7 & 3.3 & & & & \\
\hline Total & 105 & 88.6 & 11.4 & 77.1 & 12.4 & 10.5 & 256 & 79 & 65 & 400 \\
\hline
\end{tabular}

${ }^{1}$ The 3 rd fieldwork period is not included as it was devoted to additional interviews with the same farmers interviewed during the 2 nd fieldwork period.

${ }^{2} \mathrm{~A}$ combination of either crop cultivation or crop and livestock production and non-agricultural income (daily labour, trade or remittance)

${ }^{3}$ Includes a variety of cereals, pulses, vegetables and tubers

${ }^{4}$ Includes both cultivated and semi-managed forest coffee. Some farmers living in villages not at coffee-growing altitude (both close to and away from forests) used coffee land in other locations.

TABLE 3 Crop raiding species ranked according to the severity of the damage they caused to crops in the Gera district of Ethiopia (Fig. 1). ${ }^{\star}$

\begin{tabular}{|c|c|c|c|}
\hline \multicolumn{2}{|c|}{ Villages located near forests } & \multicolumn{2}{|c|}{ Villages located away from forests } \\
\hline Rank & Species & Rank & Species \\
\hline 1 & Olive baboon Papio anubis & 1 & Vervet monkey Cercopithecus aethiops \\
\hline 1 & Bush pig Potamochoerus larvatus & 2 & Porcupine Hystrix cristata \\
\hline 3 & Giant forest hog Hylochoerus meinertzhageni & 3 & Bush pig \\
\hline 4 & Vervet monkey & 4 & Colobus monkey Colobus guereza \\
\hline 5 & Warthog Phacochoerus africanus & & \\
\hline 6 & Porcupine & & \\
\hline 7 & Colobus monkey & & \\
\hline 8 & Blue monkey Cercopithecus mitis & & \\
\hline
\end{tabular}

*The ranking is based on focus group discussions conducted during the 1st and 4th fieldwork periods (Table 1). Although foxes, civets, common duikers Sylvicapra grimmia and birds were reported as pests by many individual farmers on forest margins, they are not included here as they were mentioned and ranked at only a few discussions. Farmers in villages located far from the forest edge reported mole rats as a common pest but these are not included as our focus is on forest-dwelling wild mammals.

by the 2007 Wildlife Development, Conservation and Utilization Proclamation (Federal Negarit Gazeta, 2007). The farmers reported that they were aware that hunting could lead to imprisonment and fines. A 90-year-old woman from a village near the forest edge made the following comment:

In the past we would shoot at the wild mammals, which scared them away, but... now it is forbidden and the animals [pests] do not fear us. .. It must be a curse.

Semi-managed forest coffee production was reported as a cause of forest degradation and loss of habitat for wildlife, driving monkeys, for example, to visit planted woodlots, cultivated coffee patches and home gardens near forest edges. In some of the coffee-growing parts of the district farmers also reported an increase in tree cover, which simultaneously led to an exacerbation of the pest problem by attracting wildlife; for example, at the forest edges in Wanja Kersa and Sadi Loya kebeles farmers reported an expansion in forest cover around their villages (Fig. 1). During 20012010 forest cover in Wanja Kersa and Sadi Loya increased by 2.8 and 1.3 ha per year, respectively (T.G. Ango et al., unpubl. data). The major reasons reported for this increase in tree cover include expansion of coffee cultivation and shade trees, and plantation forest. 
TABLE 4 Percentages of fields visited by at least one type of wild mammal pest (based on data from 2nd fieldwork period), farmers' reported level of maize ( 3 rd fieldwork period) and enset (2nd fieldwork period) yield loss, and trends in crop raiding during 2007-2011 (2nd fieldwork period). ( $\mathrm{n}$ is the total number of fields per land use type or interviewed farmer in villages along the transects from which the percentages were calculated, or the total number of fields along the transects for which the means were calculated.)

\begin{tabular}{|c|c|c|c|c|c|c|c|c|c|c|c|c|}
\hline \multirow[b]{2}{*}{$\begin{array}{l}\text { Transect } \\
\text { location }\end{array}$} & \multicolumn{4}{|c|}{$\%$ fields visited by at least one type of wild mammal } & \multicolumn{3}{|c|}{ Maize field area $\&$ yield $\operatorname{loss}^{3}$} & \multirow[b]{2}{*}{$\begin{array}{l}\text { \% farmers who } \\
\text { reported severe } \\
\text { raids of enset }\end{array}$} & \multicolumn{4}{|c|}{$\begin{array}{l}\text { \% farmers who reported trends in wild mam- } \\
\text { mal crop raiding during 2007-2011 }\end{array}$} \\
\hline & Annual crop ${ }^{1}$ & $\begin{array}{l}\text { Home } \\
\text { garden }\end{array}$ & Coffee $^{2}$ & Total & $\begin{array}{l}\text { Mean area } \pm \text { SE } \\
\text { (ha) }\end{array}$ & $\begin{array}{l}\text { Mean yield } \\
\operatorname{loss} \pm \mathrm{SE} \\
(\mathrm{kg})\end{array}$ & $\begin{array}{l}\% \\
\text { final } \\
\text { yield } \\
\text { loss }\end{array}$ & & Increased & Decreased & Other $^{4}$ & Total \\
\hline $\begin{array}{l}\text { Near } \\
\text { forests }\end{array}$ & $83.1(\mathrm{n}=71)$ & $93.1(\mathrm{n}=29)$ & $81.5(\mathrm{n}=27)$ & $85.0(\mathrm{n}=127)$ & $0.31 \pm 0.05(\mathrm{n}=14)$ & $243 \pm 65$ & 34.2 & $74.1(\mathrm{n}=27)$ & 66.7 & 18.5 & 14.8 & $100(\mathrm{n}=27)$ \\
\hline $\begin{array}{l}\text { Away from } \\
\text { forests }\end{array}$ & $67.1(n=82)$ & $77.8(\mathrm{n}=27)$ & $88.2(\mathrm{n}=17)$ & $72.2(\mathrm{n}=126)$ & $0.30 \pm 0.09(\mathrm{n}=7)$ & $80 \pm 13.6$ & 11.5 & $25.9(\mathrm{n}=27)$ & 48.2 & 22.2 & 29.6 & $100(\mathrm{n}=27)$ \\
\hline $\begin{array}{l}\text { P (near vs } \\
\text { away from } \\
\text { forests) }\end{array}$ & 0.037 & 0.209 & 0.863 & 0.02 & & & & 0.001 & 0.271 & 1.0 & 0.326 & \\
\hline
\end{tabular}

${ }^{1}$ Includes a variety of cereals, pulses, vegetables and tubers

${ }^{2}$ Both cultivated and semi-managed forest coffee

${ }^{3}$ Despite the likelihood that information received from farmers may overestimate the impact of pests, based on our triangulation using various data collection methods, including observation during four fieldwork periods over 3 years, it is clear that the yield loss estimated by farmers reflects the extent of the crop raiding problem in the area.

${ }^{4}$ Includes no change and fluctuating trends 
TABLE 5 The extent to which farmers used crop raiding mitigation strategies during the 2011 cropping season. (n is the total number of fields per land use type or interviewed farmer in villages along the transects from which the percentages were calculated, or the total number of fields along the transects for which the means were calculated.)

\begin{tabular}{|c|c|c|c|c|c|}
\hline \multirow[b]{2}{*}{$\begin{array}{l}\text { Transect } \\
\text { location }\end{array}$} & \multicolumn{2}{|c|}{$\begin{array}{l}\% \text { fields where farmers used } \\
\text { at least one mitigation strat- } \\
\text { egy ( } 2 \text { nd fieldwork period) }\end{array}$} & \multirow{2}{*}{$\begin{array}{l}\% \text { annual crop fields where } \\
\text { protection shelters }(\text { godo })^{*} \\
\text { were used for guarding } \\
\text { (1st fieldwork period) }\end{array}$} & \multirow{2}{*}{$\begin{array}{l}\% \text { farmers who gave up land } \\
\text { through crop sharing or yeku- } \\
\text { to for any reason } \\
\text { (2nd fieldwork period) }\end{array}$} & \multirow{2}{*}{$\begin{array}{l}\% \text { farmers who gave up } \\
\text { land through yekuto } \\
\text { because of crop raiding } \\
\text { (2nd fieldwork period) }\end{array}$} \\
\hline & Annual crops & $\begin{array}{l}\text { Home } \\
\text { garden }\end{array}$ & & & \\
\hline Near forests & $94.9(\mathrm{n}=59)$ & $92.6(\mathrm{n}=27)$ & $64.4(\mathrm{n}=45)$ & $74.1(\mathrm{n}=27)$ & $35.0(\mathrm{n}=20)$ \\
\hline $\begin{array}{l}\text { Away from } \\
\text { forests }\end{array}$ & $76.4(\mathrm{n}=55)$ & $85.7(\mathrm{n}=21)$ & $58.0(\mathrm{n}=50)$ & $59.3(\mathrm{n}=27)$ & $6.3(\mathrm{n}=16)$ \\
\hline Total & $86.0(\mathrm{n}=114)$ & $89.6(\mathrm{n}=48)$ & $61.1(\mathrm{n}=95)$ & $66.7(\mathrm{n}=54)$ & $22.2(\mathrm{n}=36)$ \\
\hline $\begin{array}{l}\chi^{2} \text { (near vs } \\
\text { away from } \\
\text { forests) }\end{array}$ & 6.655 & 0.089 & & 0.750 & 2.750 \\
\hline $\begin{array}{l}P \text { (near vs } \\
\text { away from } \\
\text { forests) }\end{array}$ & 0.010 & 0.766 & & 0.387 & 0.097 \\
\hline
\end{tabular}

*Some godo are towers, constructed to facilitate guarding of crops. Two or more fields sometimes shared one godo, and fields with two protection shelters were also observed.

\section{Mitigation of crop raiding by wild mammal pests}

Farmers used the following strategies and practices to mitigate crop raiding by wild mammals: guarding, didaro (crop cooperation), yekuto (crop sharing), migration, removal of trees from crop fields, fences, decoys (e.g. scarecrows), traps, smoke (e.g. smoking bones to scare away nocturnal pests), tying tape from old cassettes to wooden poles around fields to scare pests, and digging out or filling in the burrows of pests such as porcupines. Migration and removal of trees from crop land have been discussed elsewhere (Ango et al., 2014). Apart from these, guarding, didaro and yekuto were the most important pest mitigation strategies.

Guarding Continuous guarding was the main strategy used to mitigate crop damage by pests. Farmers in all villages stated that this was necessary to obtain harvests of annual crops such as maize, sorghum and pulses, but the need was most acute in villages near forests (Table 5). All household members except children younger than c. 7 years participated in crop guarding at various times of the day and to varying degrees. Annual crops were guarded from the day of sowing until the crops were harvested and stored in granaries. For perennial crops such as enset, protection was year-round. For maize cultivated at forest edges the protection time was up to 6 months in villages at higher altitudes, where maize takes longer to mature. In relation to this a 66-year-old man at a focus group discussion stated:

We are always there to protect the crops from pests. If we stop guarding the crop fields because of sickness, social responsibilities such as funerals, or even going home for lunch, we find damage to the crops from pests, sometimes even loss of the entire crop.
In villages away from forests the duration of crop guarding was short, normally covering only the first month after sowing and the last 2 months before harvest. In many places crop guarding was supported by one or more protection shelters (godo, Plate 1, Table 5); the two most common types were platforms for crop protection at night (Plate 1a,b) and shelters for pest protection during the day (Plate 1c). The night-time protection platforms were used as resting places at night and as protection against bush pigs, and were mostly found in villages near forests.

Didaro is a local institutional arrangement used to complement continuous guarding of crops. Under this arrangement farming households plant similar crops in fields adjacent to each other around the same time to mobilize labour for crop protection (Plate 2). If most farmers decide to fallow their land near forest edges the rest tend to accept the decision and also fallow their lands because they would face significant crop protection challenges if they decided to cultivate. Accordingly, many instances of forced fallowing of fields near forest edges were reported. Didaro implies that farmers protect their own fields from pests, with frequent exchange of information about pests between neighbouring farmers. It is this exchange of information and the presence of many people on adjacent fields that make didaro an effective pest protection strategy. Farmers in villages near forests perceive that this cooperation is necessary to make the effort of cultivating worthwhile. The burden of crop damage is shared by adjacent crop fields, and it was common for farmers living near forests to emphasize the general sentiment that 'one alone cannot cultivate and feed oneself.

Yekuto is an institutional arrangement usually made between two parties to govern how assets such as land, livestock and labour are accessed and used for various 


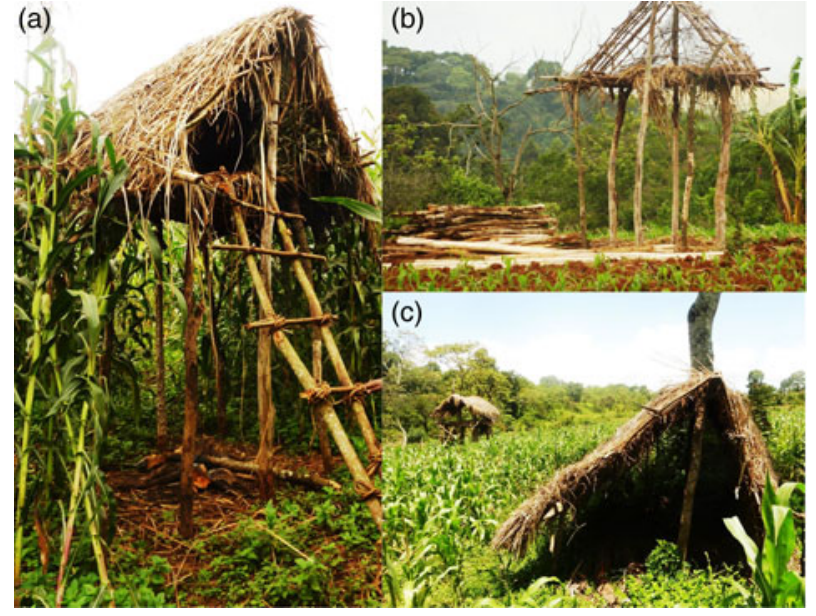

Plate 1 Crop protection shelters (godo) in use (a \& c) and under construction (b) in the study area in the Gera district of Ethiopia (Fig. 1).

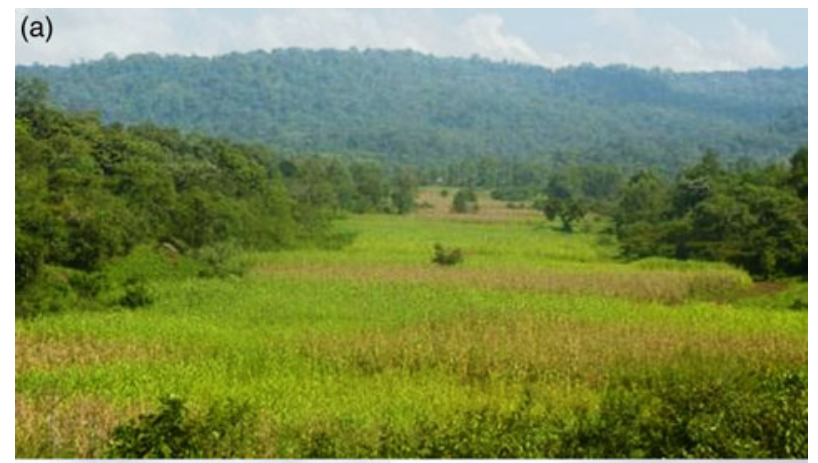

(b)

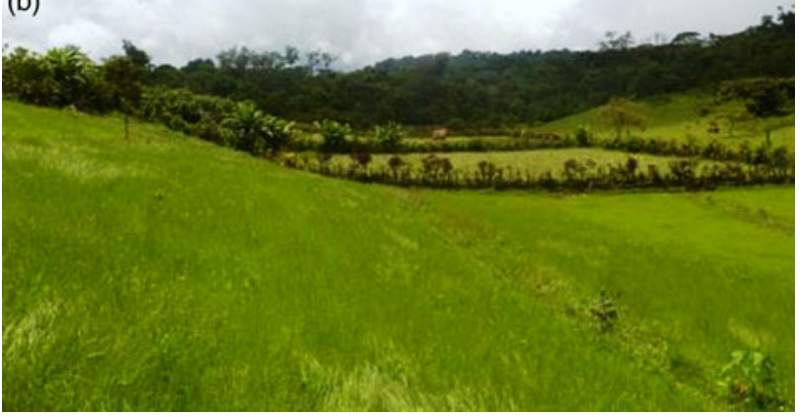

Plate 2 Maize (a) and tef (b) cultivated in adjacent fields in the Gera district of Ethiopia (Fig. 1) under a didaro arrangement.

production activities, including crop production. The basic principle is that both parties cover comparable production costs in the cropping season and share the yield equally. Yekuto was common in the study area, with two-thirds of the interviewed farmers giving land to others under this arrangement (Table 5). More farmers living near forests gave cropland through yekuto (to mitigate pest problems) compared to those living away from forests ( $35 \mathrm{vs} 6 \%, \mathrm{P}=0.097$; Table 5). Yekuto helped farmers living near forest to deal with wild mammal pests in two ways. Firstly, they could give their land on the forest edges to other farmers with sufficient resources for crop protection, to cultivate for a year or more. Secondly, they could gain access to land in areas away from forests, where there were fewer or no pests, although this required travelling long distances back and forth to cultivate these fields. Farmers who had experience of hiring labour for crop protection indicated that yekuto was a more effective strategy. In yekuto, farmers endeavoured to reduce the damage caused by pests, as this damage would reduce the yield they would share. The performance of the various parties in yekuto informed the decision regarding whether or not the arrangement should be retained for the next season.

\section{Effects of wild mammal pests on local livelihoods}

Yield loss Fourteen farmers living near forests were asked whether their main maize field was raided by pests; all responded in the affirmative. The mean loss of maize yield to pests was $243 \mathrm{~kg}$, or $34.2 \%$ of the total expected yield (Table 4). In comparison, the mean loss in villages located away from forests was $80 \mathrm{~kg}$, or $11.5 \%$ of the total expected yield. In villages near forests, instances of entire harvests of maize and tef being damaged by pests were also reported, and during fieldwork we observed two maize fields that had been completely destroyed. Enset, another staple crop, was also reported to be severely damaged by wild mammal pests, mainly in villages near forests (Table 4, P=0.001). A 6o-year-old widow reported that most of the enset seedlings she planted were damaged overnight by porcupines and bush pigs. Most of the crops cultivated in the study area required some kind of protection from pests and for many farmers a shortage of labour to protect crops meant that yield loss could not be avoided.

Labour costs for crop protection In villages near forests crop protection was a full-time job for at least one person during the cropping season. The cost of hiring labour for crop protection was generally paid in kind at c. $20 \%$ (by weight) of the crop yield from the guarded field. Construction of godo also required additional investment in labour, with farmers near forests reporting that construction of a new shelter for night-time protection required c. 7 person-days whereas farmers away from forests spent 1-2 days constructing daytime shelters.

Investment in agriculture Several farmers near forests explained that they did not use agricultural technologies such as chemical fertilizers and improved crop varieties because of the problem of crop raiding by wild mammals, as the resulting lower yields counterbalanced any return 
on their investment, as reported by a 56-year-old man living at the forest edge:

This year [the 2013 cropping season] I bought chemical fertilizer for ETB 1,470 [USD 1 = ETB 19.24 on 10 March 2014] and maize seeds for ETB 202 . . But I was forced to sell the young maize for about ETB 200 because we [his family] were not able to protect the crop from baboons.

Another man in his mid 5os made it clear that farmers living near forests 'do not want to invest for baboons' even though the local government was advising them to buy and use chemical fertilizers and improved seeds.

Food security Along the forest edges crop raiding and the resulting need for protection were major constraints to agricultural practices. As a result, households, particularly those headed by females or older people, were exposed to hunger as they lacked the labour needed to protect their crops.

In the past, three to four mature enset would fall and rot in my garden, as there were more enset than we could use. Nowadays, with age, things are bad. I am sitting here half blind, making noise to scare the baboons away. (An older man living near the forest edge)

Now we are starving as a result of pests. A couple of years ago pests totally damaged all the cabbage we cultivated... These days the garden is empty; the pests damaged everything, including chickens and young sheep. It's raining and we have fertile soil but we have to just sit here instead of cultivating anything, because of pests. (A 70-year-old woman living near the forest edge)

Farmers near forests also reported that the frequency of cultivation of pulses (e.g. field beans and peas) and other crops preferred by pests (e.g. sorghum) was reduced, particularly in the years when didaro and/or yekuto were not implemented. Pulses were particularly at risk as even slight trampling could result in the entire crop being lost. The vulnerability of pulses to crop raiding is encapsulated in a local proverb: Aatoon cabaa namaa fayyisa malee cabaa ofii hin fayyisu (peas can repair broken human legs but not their own).

Children's absence from school School absenteeism to fulfil the need for crop protection was a problem mentioned by several informants, especially in villages near forests. A 13-year-old boy who was interviewed while protecting a flowering maize field near the forest edge said that he could not go to school because of his responsibility for crop protection. Principals and teachers of schools near forest edges also reported crop guarding as a factor in school absenteeism, particularly in April, September and early October. Furthermore, it was reported that in some cases children had quit going to school altogether to meet the demand for labour to guard crops.

\section{Discussion}

Our findings indicate that crop raiding by wild mammals, and associated indirect costs, have a negative impact on agricultural development and food security in villages at forest margins, whereas villages at a distance from forests experience more tolerable levels of raiding (Naughton-Treves, 1997; Lemessa et al., 2013; Mc Guinness \& Taylor, 2014).

Our results highlight the importance of identifying threats to specific and critical components of the farming system and local livelihoods. Enset and maize, which were particularly targeted by pests (Table 4), are not only major staple crops but are also essential for sustaining food security during the food deficit period before the main harvest. Moreover, the tendency of farmers to avoid cultivating pulses, particularly in the years when didaro and/or yekuto are not implemented, can have a depressing effect on overall food security as these crops are important not only as a protein source but also as a source of cash income and as nitrogen fixers in crop rotations. This susceptibility of staple crops and pulses, coupled with the difficulty of cultivating vegetables and raising poultry and sheep along forest margins, shows the vulnerability of many farming households to pests. Households headed by women or older people were often the most vulnerable as they generally had fewer members with the capacity to participate in crop protection activities.

Another important finding is farmers' lack of interest in using chemical fertilizers and improved seeds because of the risk of raiding by pests. For many farmers the risk of losing much of their harvest to pests (Table 4) acts as a disincentive to make substantial investments to raise agricultural productivity. Thus, the problem of crop raiding has a negative impact on agricultural production in Gera and works against the national policy promoting the use of chemical fertilizers and improved seeds by smallholding farmers as a strategy for agricultural and rural development (FDRE, 2003).

The importance of coordinated pest management is highlighted by farmers' use of mitigation strategies such as guarding, fencing, decoys (Osborn \& Hill, 2005; Quirin \& Dixon, 2012) and the local institutional arrangements of $d i$ daro and yekuto. Their ability to reduce crop damage caused by wild mammals relies both on the capacity of individual households to guard crop fields and on local institutions. The practice of yekuto (Table 5), for example, increases the viability of crop cultivation near forests by redistributing labour resources across the landscape. Yekuto arrangements may thus be a contributing factor in the lack of a clear difference in crop mix and land use between villages near and far from forests despite the higher frequency of crop raiding near forests (Lemessa et al., 2013). How farmers mobilize local institutions to mitigate crop raiding has received relatively little scientific attention in an Ethiopian context (but see Dixon, 2008; Dixon et al., 2009). However, our findings suggest that such institutions can have a decisive impact on the ability of smallholding farmers to cultivate close to forests. 
Crop guarding is a labour-intensive activity (Hill, 2000; Tweheyo et al., 2012). Farmers in Gera also need to travel long distances to cultivate fields under crop-sharing arrangements, which further competes with the demands for labour for ploughing, weeding and coffee management. The availability of year-round employment opportunities in private coffee producing companies, albeit temporary and with low pay (c. ETB 20 per person per day), exemplifies another opportunity cost related to crop protection in Gera, and the burden this places specifically on poor families whose members are willing to take these jobs (T.G. Ango, unpubl. data).

Forest and trees managed on agricultural land in Gera are valued for a number of important ecosystem services, including shade for coffee (Hylander et al., 2013), honey production and wood products for energy and construction. Striking a balance between these services and the disservices from and related to trees is not always straightforward (Ango et al., 2014). As the human population in the area has doubled since 1984 and is expected to increase further (CSA, 2013; T.G. Ango et al., unpubl. data), and forest cover has been declining (Hylander et al., 2013), an increase in the likelihood of people and wildlife coming into contact can be expected.

It has been recognized that a narrow focus on humanwildlife interactions is often misleading, as such conflicts may be directly linked to conflicting interests and power asymmetries within societies (Dickman, 2010; Hill, 2015). Although our study had an explicit focus on the impact of pests on local livelihoods and local mitigation strategies, our results also expose how conflicting conservation and development interests lie at the heart of the problem of crop raiding pests in Gera. One example is the government's confiscation of rifles and banning of hunting, which according to farmers has resulted in increased numbers of wild mammals and exacerbated the pest problem, with negative effects on local development (e.g. school absenteeism and farmers' reluctance to invest in agriculture). The local government has so far not prioritized mammal pests as an acute problem in the same way as local farmers have, and no support has been given to farmers to mitigate the problem (Agriculture and Rural Development Office, pers. comm.). The Oromia Forest and Wildlife Enterprise Jimma Branch Office and other district offices have made it a priority to oversee the implementation of state policies for wildlife conservation.

To reduce human-wildlife conflict and identify more viable mitigation strategies the local government in Gera needs to recognize the direct and indirect costs of wild mammals for farmers. We recommend a combination of strategies, including the recognition and promotion of local institutions, didaro and yekuto, whenever considered appropriate by farmers. This could include, for example, the development of deterrents (Hsiao et al., 2013) that are simple to use and locally relevant (Hill \& Wallace, 2012).
The cost of such deterrents should be funded externally (Balmford \& Whitten, 2003; Mackenzie \& Ahabyona, 2012), for example, by the Oromia Forest and Wildlife Enterprise Jimma Branch Office, which plans to invest some of its profits in local development. As all the wild mammals involved in crop raiding in Gera are categorized as Least Concern on the IUCN Red List (IUCN, 2015), culling could be considered as part of a government-led mitigation strategy, after identifying the ecological context of problem species and the benefits and disadvantages of culling (Treves \& Naughton-Treves, 2005; Strum, 2010). The 2007 Wildlife Development, Conservation and Utilization Proclamation delegates regional governments to conduct studies on the threat of wildlife 'to human life and property and take appropriate measure to minimize and prevent the threat' (Federal Negarit Gazeta, 2007, p. 3742). Finally, any pest mitigation strategies should also aim to minimize the negative impact of crop protection on children's schooling (Mackenzie et al., 2015).

\section{Acknowledgements}

The study was funded by grants from the Swedish International Development Cooperation Authority (contract number SWE-2009-134) and the Swedish Research Council Formas (contract number 229-2009-991) to Kristoffer Hylander. We are grateful to all participating farmers for their time and information; to our field assistants; and to Kristoffer Hylander, Jens Friis Lund and the anonymous reviewers for their insightful comments. This research was conducted in collaboration with Addis Ababa University, with a letter of support from the Regional Government of Oromia Agricultural and Regional Development Bureau (Ref. no. 4-1.3/57/04).

\section{References}

Ango, T.G., Börjeson, L., Senbeta, F. \& Hylander, K. (2014) Balancing ecosystem services and disservices: smallholder farmers' use and management of forest and trees in an agricultural landscape in southwestern Ethiopia. Ecology and Society, 19, 30.

Årlin, C., Börjeson, L. \& Östberg, W. (2015) Participatory checking and the temporality of landscapes: increasing trust and relevance in qualitative research. In Oxford Handbook of Historical Ecology and Applied Archaeology (eds C. Isendahl \& D. Stump). Oxford University Press, Oxford, UK. Http://dx.doi.org/10.1093/oxfordhb/ 9780199672691.013.19 [accessed 24 March 2016].

Balmford, A. \& Whitten, T. (2003) Who should pay for tropical conservation, and how could the costs be met? Oryx, 37, 238-250.

Barua, M., Bhagwat, S.A. \& Jadhav, S. (2013) The hidden dimensions of human-wildlife conflict: health impacts, opportunity and transaction costs. Biological Conservation, 157, 309-316.

Bryman, A. (2012) Social Research Methods, 4th edition. Oxford University Press, Oxford, UK.

CSA (Central Statistical Agency) (2013) Population Projection of Ethiopia for All Regions at Wereda Level from 2014-2017. Central 
Statistical Agency, Addis Ababa, Ethiopia. Http://www.csa.gov.et/ images/general/news/pop_pro_wer_2014-2017_final [accessed 30 July 2015].

Dickman, A.J. (2010) Complexities of conflict: the importance of considering social factors for effectively resolving human-wildlife conflict. Animal Conservation, 13, 458-466.

Dixon, A.B. (2008) The resilience and sustainability of local wetland management institutions in Illubabor and Western Wellega, Ethiopia. Singapore Journal of Tropical Geography, 29, 341-356.

Dixon, A.B., Hailu, A., Semu, T. \& Taffa, L. (2009) Local responses to marginalisation: human-wildlife conflict in Ethiopia's wetlands. Geography, 94, 38-47.

FDre (Federal Democratic Republic of Ethiopia) (2003) Rural Development Policy and Strategies. Ministry of Finance and Economic Development, Economic Policy and Planning Department, Addis Ababa, Ethiopia. Http://gafspfund.org/sites/ gafspfund.org/files/Documents/Ethiopia_4_of_6_ARD\%2opolicy. pdf [accessed 2 January 2014].

Federal Negarit Gazeta (2007) Development, Conservation and Utilization of Wildlife Proclamation. Proclamation No. 541/2007. Addis Ababa, Ethiopia. Http://www.ewca.gov.et/sites/default/files/ negarit\%20541.ae_..pdf [accessed 10 March 2014].

Haule, K.S., Johnsen, F.H. \& Maganga, S.L.S. (2002) Striving for sustainable wildlife management: the case of Kilombero Game Controlled Area, Tanzania. Journal of Environmental Management, 66, 31-42.

Hill, C.M. (200o) Conflict of interest between people and baboons: crop raiding in Uganda. International Journal of Primatology, 21, 299-315.

Hill, C.M. (2015) Perspectives of "conflict" at the wildlife-agriculture boundary: 10 years on. Human Dimensions of Wildlife, 20, 296-301.

Hill, C.M. \& Wallace, G.E. (2012) Crop protection and conflict mitigation: reducing the costs of living alongside non-human primates. Biodiversity and Conservation, 21, 2569-2587.

Hsiao, S.S., Ross, C., Hill, C.M. \& Wallace, G. (2013) Crop-raiding deterrents around Budongo Forest Reserve: an evaluation through farmer actions and perceptions. Oryx, 47, 569-577.

Hylander, K., Nemomissa, S., Delrue, J. \& Enkosa, W. (2013) Effects of coffee management on deforestation rates and forest integrity. Conservation Biology, 27, 1031-1040.

IUCN (2015) The IUCN Red List of Threatened Species v. 2015-4. Http://www.iucnredlist.org [accessed 4 March 2016].

Laudati, A.A. (2010) The encroaching forest: struggles over land and resources on the boundary of Bwindi Impenetrable National Park, Uganda. Society \& Natural Resources, 23, 776-789.

Lemessa, D., Hylander, K. \& Hambäck, P. (2013) Composition of crops and land-use types in relation to crop raiding pattern at different distances from forests. Agriculture, Ecosystems \& Environment, 167, 71-78.

Mackenzie, C.A. \& Ahabyona, P. (2012) Elephants in the garden: financial and social costs of crop raiding. Ecological Economics, 75, $72-82$.

Mackenzie, C.A., Sengupta, R.R. \& Kaoser, R. (2015) Chasing baboons or attending class: protected areas and childhood education in Uganda. Environmental Conservation, 42, 373-383.

Madden, F.M. (2008) The growing conflict between humans and wildlife: law and policy as contributing and mitigating factors. Journal of International Wildlife Law \& Policy, 11, 189-206.

Marchini, S. \& Crawshaw, Jr, P.G. (2015) Human-wildlife conflicts in Brazil: a fast-growing issue. Human Dimensions of Wildlife, 20, $323-328$

Mc Guinness, S. \& Taylor, D. (2014) Farmers' perceptions and actions to decrease crop raiding by forest-dwelling primates around a Rwandan forest fragment. Human Dimensions of Wildlife, 19, 179-190.

Naughton-Treves, L. (1997) Farming the forest edge: vulnerable places and people around Kibale National Park, Uganda. Geographical Review, 87, 27-46.

Nyhus, P.J., Osofsky, S.A., Ferraro, P., Madden, F. \& Fischer, H. (2005) Bearing the costs of human-wildlife conflict: the challenges of compensation schemes. In People and Wildlife: Conflict or Coexistence? (eds R. Woodroffe, S. Thirgood \& A. Rabinowitz), pp. 107-121. Cambridge University Press, Cambridge, UK.

Osborn, F.V. \& Hill, C.M. (2005) Techniques to reduce crop loss: human and technical dimensions in Africa. In People and Wildlife: Conflict or Coexistence? (eds R. Woodroffe, S. Thirgood \& A. Rabinowitz), pp. 72-85. Cambridge University Press, Cambridge, UK.

QUIRIN, C. \& Dixon, A. (2012) Food security, politics and perceptions of wildlife damage in western Ethiopia. International Journal of Pest Management, 58, 101-114.

R Development Core Team (2012) R: A Language and Environment for Statistical Computing. R Foundation for Statistical Computing, Vienna, Austria.

Redpath, S.M., Bhatia, S. \& Young, J. (2015) Tilting at wildlife: reconsidering human-wildlife conflict. Oryx, 49, 222-225.

Samnegåd, U., Hambäck, P.A., Nemomissa, S. \& Hylander, K. (2014) Local and regional variation in local frequency of multiple coffee pests across a mosaic landscape in Coffea arabica's native range. Biotropica, 46, 276-284.

Seifu, M. \& Beyene, F. (2014) Local livelihoods and institutions in managing wildlife ecosystems: the case of Babile Elephant Sanctuary in Ethiopia. Journal for Nature Conservation, 22, 559-569.

STRUM, S.C. (2010) The development of primate raiding: implications for management and conservation. International Journal of Primatology, 31, 133-156.

Thirgood, S., Woodroffe, R. \& Rabinowitz, A. (2005) The impact of human-wildlife conflict on human lives and livelihoods. In People and Wildlife: Conflict or Coexistence? (eds R. Woodroffe, S. Thirgood \& A. Rabinowitz), pp. 13-26. Cambridge University Press, Cambridge, UK.

Treves, A. \& Naughton-Treves, L. (2005) Evaluating lethal control in the management of human-wildlife conflict. In People and Wildlife: Conflict or Coexistence? (eds R. Woodroffe, S. Thirgood \& A. Rabinowitz), pp. 86-106. Cambridge University Press, Cambridge, UK.

Tweheyo, M., Tumusime, D.M., Turyahabwe, N., Asimme, A. \& ORIKIRIZA, L. (2012) Wildlife damage and control methods around Lake Mburo National Park, Uganda. International Journal of Pest Management, 58, 25-31.

Weladji, R.B. \& Tснамва, M.N. (2003) Conflict between people and protected areas within the Bénoué Wildlife Conservation Area, North Cameroon. Oryx, 37, 72-79.

Zhang, W., Ricketts, T.H., Kremen, C., Carney, K. \& Swinton, S.M. (2007) Ecosystem services and dis-services to agriculture. Ecological Economics, 64, 253-260.

\section{Biographical sketches}

Tola Gemechu Ango's research focuses on forest and agro-ecosystem services and management, land use change, rural livelihoods and development. LOWE BÖRJESON's research focuses on historical and current processes of landscape and agricultural change in various localities in Africa. Feyera SEnBETA's research focuses on biodiversity conservation, natural resource management, ecosystem services and rural livelihoods. 